\title{
Distributive communicative behaviour in Danish and Spanish negotiation interaction
}

\begin{abstract}
This article describes preliminary results of a comparative study of communicative behaviour in Danish and Spanish negotiation interaction. The position is taken that from a socio-psychological point of view negotiation strategies may be accounted for in terms of face needs and feeling and display rules. It is argued that distributive behaviour is prevailing in both cultures, but that the corresponding communicative patterns are completely different.
\end{abstract}

\section{Introduction}

The overall aim of this project is to analyse communicative behaviour used in Danish and Spanish negotiation interaction from an intercultural point of view. A comparison between Spanish and Danish empirical data leaves one with the immediate impression that Danish negotiators seem to be more integrative than Spanish negotiators. On closer examination it turns out, however, that distributive behaviour prevails in both cultures. In the present paper linguistic and socio-psychological aspects of the conceptual framework that make it possible to account for this seeming discrepancy will be discussed.

The data used consist of video tapes recorded during negotiation seminars arranged by Spanish and Danish training centres ${ }^{1}$. It is worth noting that the training programme used to improve the participants' negotiation skills was exactly the same in the Spanish and the Danish courses, and that in both cases the target group were professional negotiators. What was meant by improving negotiating skills? One central point is that negotiators generally use distributive behaviour, because of the competitive element inherent in negotiating activity. This is the case even in situations where the underlying conditions permit integrative outcomes. Since distributive behaviour reduces flexibility and creativity, one goal was to

\footnotetext{
${ }^{1}$ My colleagues and I are very grateful to AKTI KURSUS A/S and to CONSULTORES ESPAÑOLES for their kind cooperation. Both have invited us to attend their seminars as observers and both continuously supply us with new video tapes. We are especially grateful to AKTI KURSUS A/S who has kindly given us useful contacts all over the world in our preparations for our future research.
} 
train the participants in focusing on integrative elements that are also present in negotiating situations.

\section{Negotiation settings framework}

In social psychology negotiation interaction is generally organized with the distributive dimension as one extreme and the integrative as the other, each characterized by their own general, overall negotiation strategies (Pruitt 1981).

The game theoretical approach that has lead to the above classification is greatly influenced by utility theory (Shubik, 1983). The description of strategic behaviour is based on the game's own terms and explained by possible outcomes. It is a question of how many points are scored, where you distinguish between zero-sum games that correspond to distributive settings, and non-zero-sum games that correspond to integrative settings. This original approach was never intended to account for what was happening between the parties. In other words, the analysis of negotiation was isolated from its socio-psychological and cultural context.

Social scientists have extended this view, analysing what happens outside the 'board'. Their focus of attention is the interrelationship between the parties, one of their aims being to define and classify communicative behaviour along the above game theoretical lines.

Yet another strategy has been proposed, i.e. the subordinative (Donohue 1984, Johnston 1981). Some researchers find that this strategy is a purely theoretical construct that has nothing to do with 'real life'. One cannot possibly imagine that a negotiator would deliberately follow a subordinate line, they argue. As long as one talks about deliberate, intended overall strategies one must of course agree. It would be better to consider 'real life' as what is actually happening during the negotiation process. This is not concerned with overall strategies but with realized, emergent strategies, and in this case the existence of a subordinative strategy is certain. Since it is the aim of the study to analyse communicated strategies, as they are verbalized 'here and now', it cannot be left out of consideration.

Here the position is taken that distributive negotiating is characterized by 1) attacking behaviour that is intended to take the offensive by proposing discrediting modifications in the opponent's position or proposing changes in the negotiatior's own position to undermine the opponent's level of aspiration, 2) defensive behaviour that is used to stabilize the negotiator's expected outcomes by either rejecting whatever modifica- 
tions have been proposed by the opponent or bolstering one's own position without specific reference to the opponent's position, and 3) the subordinative behaviour where the negotiator accepts the opponent's modification to his own position, and reveals weakness and/or lack of confidence in own position (Donohue et al. 1984).

However, due to common cultural background, social scientists and negotiators to some extent rely on a mutual understanding as to how behaviour is to be interpreted, which is an obvious deficiency from an intercultural point of view. In order to overcome this shortcoming the psychological impacts of negotiation strategies are related to face needs (Goffman 1961,1967). It is claimed that distributive strategies correspond to the personal face-needs dimension that concerns personal autonomy, whereas integrative strategies correspond to the interpersonal faceneeds dimension that concerns interpersonal acceptance (Brown/Levinson 1978, Arndt/Janney 1987).

From a psychological point of view personal and interpersonal faceneeds often conflict, leading to double bind situations, the essence being a conflict between two mutually desirable options that at the same time are mutually exclusive (Arndt/Janney 1987). In the following it will be demonstrated that the apparent integrative behaviour of the Danish negotiators can be explained in terms of double binds.

\section{Interaction psychology and effect}

When the parties meet they intentionally create a temporary nearness to each other. They establish an interactive setting in which their psychological territories are confronted with each other at the expressive and psychological levels. At the expressive level the physical manifestation of this contact is directly observable and may be established in all spatial dimensions, whereas at the psychological level it is only indirectly observable and depends on the parties' immediate affective states.

In the psychological framework used here the communication of these affective states is referred to as emotive communication, and affective states are defined as relatively transitory, with uncontrollable, subconscious psycho-biological components and partly controllable expressive components (Arndt/Janney 1987). The fact that at least part of this process is controllable implies that it can to some extent be regulated by the speaker. What he intends is of course to regulate this process in such a way that he is able to maintain his cognitive-emotional and social equilibrium and adapt to the speaking situation. 
How can one account for the way in which emotive communication is regulated? Interaction psychology has described two major interrelated processes in the management of emotion. One is concerned with the appropriateness of feelings with regard to the communicative situation, i.e. what one tries to feel in a given situation. This process could be called 'deep acting' or 'emotion work' and refers to speakers' efforts to shape their feelings to bring them into accordance with feeling rules that are socio-culturally determined. Since the article focuses on an interactive account, the importance of emotional reciprocity should be emphasized. This term refers to the fact that when faced with certain emotional states speakers are expected to respond with other well specified emotional states. The other process is concerned with emotion expression, i.e. how one tries to appear to feel in a given situation. This process could be called 'surface acting' and is regulated by display rules. Display rules are also socio-culturally determined and prescribe different procedures for the management of affect display in social settings (Hochschild 1979).

Goffman's focus is on social encounters where he describes the communication of emotional states in terms of face-needs in an attempt to discover social patterns in emotive experience. In his approach, however, there is a missing link between the immediate social situation on the one hand, and socio-cultural macrostructure and personality on the other. In order to fill in this gap an intermediate position in the conceptual framework will be taken by regarding face maintenance as being regulated by both feeling rules and display rules. It is claimed that the desire to maintain face and the fear of losing it are human universals. But in an attempt to discover the underlying processes of how and why, it is necessary to explore socio-cultural factors that have an impact on personality formation. It is found that feeling rules and display rules supply the above mentioned missing link.

\section{Interpersonal communication regulation}

The communicative framework within which negotiation interaction proceeds is called a dialogue ${ }^{2}$. It could be argued that negotiation might constitute a special dialogue format (Hellspong 1988). For the moment, however, the project is primarily concerned with what happens between the parties at any time, analysing how communicative choices affect dialogue regulation.

\footnotetext{
${ }^{2}$ The implications of this choice will be accounted for in a later publication.
} 
As far as dialogue regulation is concerned, the approach here is based on the notion of language games that was originally introduced by Wittgenstein (Severinson 1983) and bears no relation to the game theoretical framework earlier discussed. Very roughly the language game model is based on the principle that any utterance can be regarded as a move in which the contents are, on the one hand, determined by the contents of some previous, often the last, utterance, and, on the other hand, carry the game on to the next utterance. The development of the language game model has taken two directions. One is analysis at the text level, where dialogue structure is regarded as hierarchic, consisting of interwoven main and sub-games. The other is analysis at the interaction level, an underlying dialogue level where the process of regulation is negotiated between the parties. What is happening at the interaction level is reflected at the text level (Severinson 1983, Hellspong 1988).

When talking about interpersonal communication regulation both dialogue levels are referred to. On the one hand, regulation is to be understood as referring to the interrelationship between the two dialogue levels, where speakers when phrasing an utterance are able to choose which level they prefer to use as communication channel. On the other hand, regulation also refers to the progressive dialogue process, i.e. exchange structures.

Whenever people engage socially they have certain expectations as to how their activities should be organized. Another important element in the language game model is based on this general observation. As far as the dialogue is concerned, speakers expect a certain degree of regularity between each new dyadic situation and similar situations they have experienced earlier. The dialogue itself gives them certain rights and certain obligations and they feel a joint responsibility that the dialogue process is regulated accordingly.

\section{Spanish vs. Danish communicative behaviour}

One main hypothesis is that whereas Spanish communicative behaviour is characterized by highly emotional speech implying that dialogue is regulated at a highly expressive level, Danish communicative behaviour is characterized by a low level of emotional speech implying that dialogue is regulated at a low expressive level. The corresponding display rules are assumed to be the following: In Spain display rules favour an overintensification, whereas in Denmark it is preferable to deintensify or try to look affectless or neutral (Ekman/Friesen 1969). 
This difference may be one of the reasons why the Spanish negotiation settings seemed more distributive. It should be pointed out of course that distributive and integrative settings are extremes in an idealized model. Empirical research shows that most negotiations should be placed somewhere between these extremes. The preliminary observation about different distributive levels does of course not exclude the possibility that integrative choices were also made. It is maintained only that they were not as frequent.

At a later stage in the project it will be analysed whether the following feeling rules apply or not: In Denmark emotions are not valued and decisions should be made on a cost-benefit basis. When discussing conflictive issues face-saving for others is crucial, since open conflicts are felt to be extremely unpleasant. In Spain emotional sensitivity is highly valued and face-saving for oneself is of crucial importance to preserve honour and dignity.

\subsection{Communicative directness vs. indirectness}

In conflictive situations communicative directness versus indirectness and control/assertiveness versus insecurity are closely related concepts, where some of the most important cues to express directness are verbal explicitness and eye contact (Arndt/Janney 1987). Typical features of Danish and Spanish dialogue structure have been analysed in this respect, and in the following a few diametrically opposite features will be pointed out.

Among researchers of emotive communication it is generally agreed that non-verbal cues are at least as important as verbal cues. Explicit emotive communication takes place at both dialogue levels, whereas implicit emotive messages are only transmitted at the underlying dialogue level, mainly through non-verbal cues. If speakers intend to display an affective state they can to some extent deliberately choose if they want to use the verbal and/or non-verbal channel. So what Ekman/Friesen (1969) call emotional leakage may in some cases be called a deliberate choice. It is assumed that in so far as verbal and non-verbal signals are congruent there is a one-to-one correspondence between emotive experience and emotion display. If verbal and non-verbal signals are non-congruent, speakers are consciously trying to adjust emotion display to the contradicting demands of the social situation. 


\subsection{Danish distributive behaviour}

Turning to conflictive issues there seems to be a marked tendency in the Danish data to keep the communication of affective states at the underlying dialogue level, i.e. verbal and non-verbal signals are non-congruent. The regulating function is to minimize or soften possible negative effects. Three characteristic features of Danish communicative behaviour in this respect have been found and they are all represented in the following example:

Eg.1. Situation: The research department has delivered a report on a newly developed product to the production department. The research managers (R1, R2) want the product to be put on the market without delay whereas the production manager $(\mathrm{P})$ thinks it is necesarry to test it once more. The situation is from the initial phases of the negotiation.

R2: BODY $</+$ GAZE

$\mathrm{R} 1: \mathrm{BODY}>/+\mathrm{GAZE}$

$\mathrm{P}: \mathrm{BODY}</$-GAZE BODY>

$\mathrm{P}:$ jeg har jo selvfølgelig et par ting som jeg $\varnothing$ vil bemærke ved det $\mathrm{V}$

I have of course a few things which I er would like to say about this

$\mathrm{P}:$ : GAZE -GAZE

$\mathrm{P}: \emptyset \mathrm{m}$ den ene ting det er at $\varnothing$ at jeg synes ikke 'helt det er 'nok at vi erm one thing is that er that I am not completely sure that it is

$\mathrm{P}$ : kun har en enkelt V afprøvnin`g

enough only to have one test

P : - GAZE/GATHERING PAPERS

R1: -GAZE/ARM $>/($ GATHERING PAPERS)

R1: nu nu det det er jeg sådan set glad for du allerede kommer ind på de`r now now that that is I am glad that you have brought this up already

R1: -GAZE +GAZE

$\mathrm{P}:$ +GAZE/ARM $>$ /HAND DOWN/ARM<

$\mathrm{P}$ : ja men jeg V tror lige jeg måske ska- ska skal jeg ikke lige prøve og

yes but I just think I perhaps shou shouldn't I just try and sum up

$\mathrm{P}$ : summere op hvad jeg har V

what I have

R1: FINGER>/-GAZE

R1: nej nej

no no

P : -GAZE

$\mathrm{P}$ : af ting fordi $\varnothing$

in the way of points because

$\mathrm{P}:$ +GAZE 


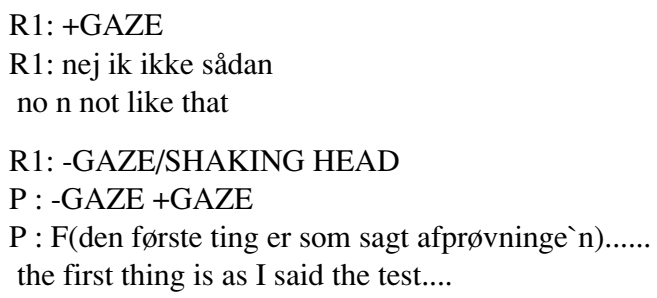

\section{Positive/negative affect display}

At the surface level of dialogue the Danish negotiators often expressed positive affect without accompanying non-verbal signals to the same effect, such as e.g. smiling and/or full gaze. In R1's first utterance he says "det er jeg sådan set glad for...".Although R1 is explicitly saying that he is 'glad', P implicitly knows that there is a discrepancy between what R1 is saying and his immediate emotive state, among other factors due to R1's averted gaze. Similar expressions without accompanying non-verbal signals could be 'det er herligt/godt/fint' ('that's great/good/fine').

It should be thought of as a universal rule that positive messages must be accompanied by signs of assertiveness and involvement in order to be interpreted as sincere. The function of expressions like the above is not to communicate that positive affect is honestly felt. These seem to be positive politeness phenomena with a conflict suppressing function.

\section{Consensus/Dissensus markers}

P's initial 'ja men' ('yes, but') is another extremely characteristic feature of the Danish negotiators' behaviour. At the surface level of dialogue it seems to signal agreement to a preceding utterance. That $\mathrm{P}$ is only superficially agreeing can be deduced from the remaining part of his utterance, where he states that he does not agree. Disagreement is toned down. It should be noted of course that the contradiction is to be found at the surface level of dialogue itself. The interesting point is, however, that the negotiators preferred a 'yes, but' to a blatant 'no' (cf. Brown/Levinson 1978), in order to tone down or soften disagreement.

\section{Prefaces}

Disclaimers are verbal expressions at the surface level of dialogue that preface potentially conflictive issues to prevent future embarrassment (Brown 1977). They are verbal qualifiers whose basic function it is to decrease the assertive power of statements. In conflictive situations they may serve two functions: 1) they are used in an attempt to soften or minimize negative effects, and 2) they are used in situations where it seems 
important to be vague so as not to exclude the possibility of later modifications. When phrasing 'disclaimers' the Danish negotiators made abundant use of modal auxiliaries (would, may, might) and attitudinal disjuncts (maybe, possibly).

Eg 2. Situation: Same play as in eg. 1:

A: kunne man så forestille sig at $\emptyset \mathrm{h}$ vi for eksempel i denne her sag what about for example in this instance we decided to er in order accepterede atøh at $\varnothing \mathrm{h}$ for at vi opnår en fælles sikkerhed gik ud til et to ensure common certainty went to another laboratory and had the andet laboratorium og fik foretaget den test for kan man så sige på test done on let us say the prodcuction department's account påø produktionsafdelingens budget

B: det vil jo nok være hvad skal vi sige lidt af af af en underkendelse af that would be what should we say something of a vote of no confiaf vores eget laboratorie hvis vi skulle gøre det dence in our own laboratory if we did that

It is important to note that not only does A's utterance, but also B's response, begin with a disclaimer, although $\mathrm{B}$ does not agree at all.

Returning to example 1, where in P's first utterance together with modal auxiliaries and attitudinal disjuncts there are other signals of decreased assertive power (question, pauses) that convey a feeling of unrestricted interpretation potential, i.e. R1 is left open to reject or accept. The following proves, however, that what $\mathrm{P}$ really intended was to keep the floor. Since R1 also wants the floor, only one possibility is left: P must raise his voice in order to get the floor back. Such disclaimers are used in situations where it seems important to be vague so as not to exclude the possibility of later modifications.

As far as dialogue regulation is concerned the general implication of these three features is that the communication of affective states is kept at the underlying dialogue level and cannot be made subject to comments without initiating a sub-game, which almost never happened in the Danish settings.

\subsection{Spanish distributive behaviour}

Spanish communicative behaviour is characterized by a high degree of explicitness/directness at both dialogue levels, also in conflictive situations. In lots of utterances verbal and non-verbal signals are congruent. Personal, direct confrontations are frequent.

Eg 3. Situation: Seller $(S)$ has just made a proposal to buyers $(\mathrm{C} 1, \mathrm{C} 2)$ for terms of 
payment.

$\mathrm{S}: \quad+\mathrm{GAZE} / \mathrm{BODY}>/ \mathrm{ARM}>$

$\mathrm{S}$ : con lo cual os pueden quedar oye unos seis o siete millone`s unos with which you can get about 5 to 6 millon 5 to 6 millon net)

seis unos cinco millones limpio`s

C1: +GAZE/BODY $><$

C1: F(pero hombre)

now look

C2: +GAZE/BODY $><$

$\mathrm{C} 2$ : exagerado

too much

S: $\quad$ ARM $>/$ HAND DOWN

S: espera

wait

C1: $\mathrm{BODY}><$

C1: F(pero hombre)

now look

S: $\quad$ BODY</ARM UP

$\mathrm{S}$ : déjame que termine

let me finish

C2: es que es mucho

this is just too much

C1: -GAZE/BODY<

$\mathrm{C} 1$ : $\mathrm{F}$ (pero hombre)

now look

C1: ARM UP-DOWN/SHAKING HEAD

S: $\quad$ ARM $><$

S: escucha déjame que termine que no he terminado hombre no te lances no just listen let me finish I'm not finished for God's sake stop

S: ARM UP

S: que pareces una moto coño entonces de los cinco millones que os que going on like that you're like a motor bike you fool now of the 5 vemos así más o menos que os pueden quedar como no queremos millon which you which let's say you you more or less can get tampoco ponernos con el agua al cuello nosotros habíamos pensado lo because we don't want you to be up to your necks we thought about siguiente a ver que os parece dos millones firmamos el contrato this let's see what do you say to 2 million we'll sign the contract 
Positive/Negative affect display

As far as affect display is concerned, whether the emotive states are honestly felt or not, negative affect display is often made. The fewer accompanying signals to reduce the intensity and assertive power of such messages the more aggressive or confrontative they are. In the Spanish material there are several examples of commentaries on current negative emotive states that are directly verbalized and accompanied by highly emotive non-verbal signals. S's last utterance is one example, although it should be noted of course that in this case the assertive power is decreased due to a sudden shift to verbal informality. The following example is much more confrontative:

Eg 4. Situation: Same as in eg. 1. $\mathrm{A}$ and $\mathrm{B}=$ research, $\mathrm{C}$ and $\mathrm{D}=$ production.

A: no pero es que no me habeis escuchado anteriormente.. no but you've not listened to what I said before

D: si yes I did

B: deja deja oir la propuesta let's let's just hear the proposal

D: quizas no te hayas leido convenientemente el informe maybe you've not read the report thoroughly

A: si me lo he leído si me lo he leído o sea creo creo notar un cierto tono I most certainly have read it I most certainly have read it and I think I sarcástico por tu parte cosa que no me esta gustando can detect a certain amount of sarcasm on your part and I do'nt like that

\section{Consensus/dissensus markers}

Initial phrasings as 'si, pero' ('yes, but') are extremely rare compared to 'no' ('no'), implying a behaviour that can only be interpreted as directly confrontative. The power of on one single 'no' is often not enough, but must be followed by a string of 'high-pitch no's' and/or by personal attention markers. Repetitive exchange structures are a very characteristic feature in Spanish communicative patterns, also in conflictive situations.

Eg. 5: Situation: $\mathrm{D}=$ buyer and $\mathrm{A}=$ seller.

D no hombre

no now look here

A eso lo sacas tu hombre..

that's what you'll get out of it 
D no hombre tu sabes

no now look here

A hombre que va

God what in hell are..

\section{Prefaces}

Turning to prefaces in the Spanish material they exceed the Danish markers in number, but, what is more important, the predominant prefaces are of quite a different kind implying communicative directness. Two types should be mentioned: 1) terms of address ((e.g. first name, hombre, chico) (first name, look, now look here)) and 2) imperatives ((mira, oye, (tú) fíjate, (tú) imagínate, ten en cuenta, escucha) (look, listen, imagine, remember)). Their function is primarily to attract attention and are often used in connection with conflictive issues.

Returning to example 3 this example, like the Danish example 2, is also about breach of turn-taking rules. The important point is, however, that the exchange pattern turns into a personal confrontation between the parties, alternating between terms of address signalling negative assessment and imperatives to call for attention.

\section{Concluding remarks}

The result of the preliminary investigations, however slight it is, gives support to the idea that in order to suppress conflicts, which are felt to be extremely unpleasant, Danish display rules favour behaviour that is characterized by the use of expressions that decrease the assertive power of statements. Since in similar situations in Spain it seems to be of crucial importance to protect one's own face, and since emotional sensivity is valued, display rules favour expressions that increase the assertive power of statements.

Transcript notations used

$$
\begin{aligned}
& + \text { GAZE }=\text { full gaze }- \text { GAZE }=\text { averted gaze } \\
& >=\text { forward }<=\text { backward } \\
& \text { ' = emphatic word stress } \\
& \text { = falling terminal } \\
& \text { ' = rising terminal } \\
& \mathrm{F}=\text { loudness } \\
& \mathrm{V}=\text { pause }
\end{aligned}
$$




\section{Literatur}

Arndt, H., Janney, R.W. (1987): Intergrammar. Toward an intergrative model of Verbal, Prosodic and Kinesic Choices in Speech. Berlin: Mouton de Gruyter.

Blom, Asger (1989): Forhandlingsspil. Odense: Pluridicta.

Bowers, J.W./Metts, S.M./Duncanson, W.T. (1985): "Emotion and Interpersonal Communication", in: Handbook of Interpersonal Communication, edt. by Knapp, M.L., Miller, G.R. Beverly Hills: Sage Publications, 500-550.

Brown, P./Levinson, S. (1978): "Universals in language usage: Politeness phenomena", in: Questions and Politeness. Esther N. Goody (ed.). Cambridge University Press.

Crespo, Eduardo (1986): "A regional Variation: Emotions in Spain", in: The Social Construction of Emotion. Rom Harré (ed.). Oxford: Basil Blackwell.

Donohue, William A./Diez, Mary E./Hamilton, Mark (1984): "Coding naturalistic negotiation interaction", in Human Communication Research, Vol. 3, No. 3, 1984, 403-425.

Druckman, D. (ed.). (1977): Negotiations, social-psychological Perspectives. London: Sage Publications.

Ekman, P., Friesen W.V. (1969): "The Repertoire of Nonverbal Behaviour: Categories, Origins, Usage, and Coding", in: Semiotica 1, 1969, 49-98.

Goffman, E. (1961): Encounters. Two Studies in the Sociology of Interaction. Indianapolis, IN:Bobbs.

Goffman, E. (1967): Interaction Ritual. Essays on face-to-face behaviour. Garden City, N.Y.: Anchor.

Goffman, E. (1972): "On face-work. An analysis of ritual elements in social interaction", in: Laver \& Hutcheson 1972, 319-346.

Hellspong, L. (1988): Regulation of Dialogue. A Theoretical Model of Conversation with an Empirical Application. Stockholm: Stockholm University, MINS 30.

Hochschild, A.R. (1979): "Emotion Work, Feeling Rules and Social Structure", in: American Journal of Sociology 85, 551-575.

Johnston, Robert W. (1982): "Negotiation Strategies: Different Strokes for Different Folks", in: Personnel 59, 36-44.

Lampi, M. (1986): Linguistic Components of strategy in business negotiations. Helsinki: Helsinki School of Economics, Studies B-85.

Linell, P., Gustavsson, L. (1987): Initiativ och respons. Om dialogens dynamik, dominans och koherens. Linkõping: Linköping University, SIC 15.

Pomerantz, A. (1984): "Agreeing and disagreeing with assessments", in: Structures of Social Action. Studies in Conversation Analysis, edited by Atkinson, M., Heritage, J. Cambridge: Cambridge University Press, 57-101.

Pruitt, Dean G. (1981):Negotiation Behaviour. New York: Academic Press.

Severinson Eklundh, K. (1983): The Notion of Language Game - A Natural Unit of Dialogue and Discourse. Linköping: Linköping University, SIC 5.

Shubik, Martin (1983): Game Theory in the social sciences, vol. 1. Cambridge: The MIT Press.

Wagner, Johannes. Petersen Uwe Helm (1988): Zur Definition von Verhandlen - unter besonderer Berücksichtigung von Geschäftsverhandlungen. Odense: Pluridicta. 
